\title{
The Contingent Attorney's Fee Tax Trap: Ethical, Fiduciary Duty, and Malpractice Implications
}

\author{
Gregg D. Polsky \\ University of Georgia School of Law, gregg.polsky@uga.edu
}

Prepress $S$ Tren

\section{Repository Citation}

Gregg D. Polsky, The Contingent Attorney's Fee Tax Trap: Ethical, Fiduciary Duty, and Malpractice Implications , 23 Va. Tax Rev 615 (2004),

Available at: https://digitalcommons.law.uga.edu/fac_artchop/1103

This Article is brought to you for free and open access by the Faculty Scholarship at Digital Commons @ University of Georgia School of Law. It has been accepted for inclusion in Scholarly Works by an authorized administrator of Digital Commons @ University of Georgia School of Law. Please share how you have benefited from this access For more information, please contact tstriepe@uga.edu. 


\section{THE CONTINGENT ATTORNEY'S FEE TAX TRAP: ETHICAL, FIDUCIARY DUTY, AND MALPRACTICE IMPLICATIONS}

Gregg D. Polsky*

\section{TABLE OF CONTENTS}

I. THE MECHANICS OF THE AMT TRAP.

II. TWO RECENT NON-TAX CASES

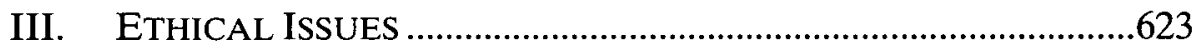

A. Conflict of Interest ...........................................................623

1. Juncture \#1: Taking the Case ......................................624

2. Juncture \#2: Settlement Offers ....................................624

3. Juncture \#3: The Motion for Fees.................................625

B. Keeping the Client Reasonably Informed...........................626

IV. FIDUCIARY DUTY \& MALPRACTICE IMPLICATIONS ...............627

A. The Fiduciary Duties of a Lawyer with Knowledge ...........628

B. Malpractice Implications ..................................................629

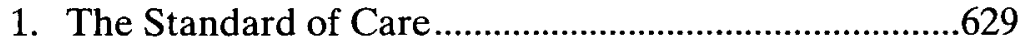

2. Causation \& Damages .............................................632

V. A LoOSE END-TAX TREatMent OF MALPRACTICE AWARDS...

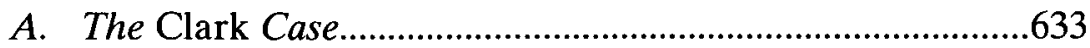

B. The Tax Benefit Rule .......................................................635

- Associate Professor, University of Minnesota Law School. I wish to thank Martin J. McMahon, Jr., Robert J. Peroni, John S. Dzienkowski, Leandra Lederman, Brant Hellwig, and Victor Fleischer for comments on an earlier draft. I also thank Maury Landsman and David McGowan for helpful discussions on the topic of this Essay, and Eliot Wren for excellent research assistance. Finally, I thank my wife, Rina Lyubkin, for her help on this project. Of course, any errors are my sole responsibility. 
The tax treatment of contingent attorney's fee arrangements has been the subject of significant debate and controversy. ${ }^{1}$ In employment and civil rights lawsuits, the alternative minimum tax $(\mathrm{AMT})^{2}$ may cause a plaintiff's ultimate recovery to be taxed at rates significantly higher than the current maximum rate of 35 percent. $^{3}$ In fact, if the ratio of attorney's fees and costs to the overall settlement amount is high enough, a plaintiff can be taxed on her net recovery ${ }^{4}$ at a rate higher than one hundred percent. ${ }^{5}$ In other words, this AMT trap may result in a victorious plaintiff owing an amount in taxes greater than her net recovery. ${ }^{6}$

I and other commentators have noted that this tax trap clearly violates tax policy principles. ${ }^{7}$ Furthermore, Professors Laura Sager and Stephen Cohen have argued persuasively that the trap "undermines the national policy of encouraging the pursuit of meritorious civil rights claims.", In addition to these policy concerns,

1 See 2002 IRS ANN. REP. TO CONG. 161-66 [hereinafter NATIONAL TAXPAYER ADVOCATE REPORT] (describing the circuit court split on the issue).

2 Though beyond the scope of this Essay, the AMT will be the cause of much more wide-ranging tax problems. Because of various structural flaws, this tax, which was designed to ensure that the extremely rich pay some amount of income tax, will soon affect a huge number of middle-class taxpayers. See Leonard E. Burman et al., The AMT: Projections and Problems, 100 TAX NoTES 105 (July 7, 2003) (projecting that by 2010 one-third of all taxpayers and $92 \%$ of households with income between $\$ 100,000$ and $\$ 500,000$ will be subject to the AMT).

${ }^{3}$ See Gregg D. Polsky, A Correct Analysis of the Tax Treatment of Contingent Attorney's Fee Arrangements: Enough with the Fruits and Trees, 37 GA. L. REV. 57, 64 67 (2002) (describing the impact of AMT in these cases). For a discussion of the types of cases in which this problem may arise see id. at 60 n.9. Most commonly, the problem arises in employment related lawsuits, such as age or sex discrimination.

4 I use the term "net recovery" to mean the plaintiff's pre-tax recovery after paying attorney's fees and costs.

5 Kenseth v. Commissioner, 114 T.C. 399, 425-26 (2000) (Beghe, J., dissenting). ${ }^{6}$ Id.

7 See Robert J. Peroni, Reform in the Use of Phaseouts and Floors in the Individual Income Tax System, 91 TAx Notes 1415, 1425 (May 28, 2001); Polsky, supra note 3, at 68-73; James Serven, Oral Argument in Hukkanen-Campbell: Taxpayer's Last Stand?, 93 TAx NoTES 854, 859 (Nov. 5, 2001); Robert W. Wood, Even Tax Court Itself Divided on Attorneys' Fee Issue!, 88 TAX NOTES 573, 573 (July 24, 2000).

${ }^{8}$ Laura Sager \& Stephen Cohen, How the Income Tax Undermines Civil Rights 
the trap has resulted in a significant amount of tax litigation, ${ }^{9}$ with plaintiffs attempting to avoid the onerous tax results by making creative, though mostly unsuccessful, arguments. ${ }^{10}$ The solution to these problems is quite simple: Congress should amend the Internal Revenue Code (Code) to allow attorney's fees expended in the pursuit of a taxable recovery to be fully deductible for AMT purposes. ${ }^{11}$ However, to date Congress has not yet seen fit to resolve the issue, presumably because the victims (i.e., the plaintiffs) ${ }^{12}$ of this

Law, 73 S. CAL. L. REV. 1075, 1078 (2000). As this article explains, I would hasten to add that this undermining will occur only if the potential victims become aware of the AMT trap prior to, or during, their pursuit of the claim. An unknowing victim will still prosecute the claim only to realize later, when he files his tax return, the pernicious effects of the trap.

9 See National TAXPayer Advocate Report, supra note 1, at 164-65 (describing the litigation).

10 See Polsky, supra note 3, at 78-120 (analyzing the plaintiff's argument that the contingent fee agreement transfers a portion of the underlying claim to the attorney, and also analyzing the plaintiff's argument that the contingent fee agreement results in a partnership for tax purposes).

1 See NAtional TAXPayer Advocate Report, supra note 1, at 169 (advocating that section 62 be amended to add these deductions to those which are taken into account in computing the taxpayer's adjusted gross income); see also Polsky, supra note 3 , at 120 .

12 Defendants may also be victimized by the tax trap because the trap could raise the cost of settlement. However, as discussed below, in certain cases the trap may help defendants by inhibiting the prosecution of some cases or by forcing the plaintiff into an early, lowball settlement. See infra notes 43-48 and accompanying text (describing the pressures that the tax trap may put on plaintiffs). Defendants would be more directly affected if they were required, pursuant to relevant federal or state law, to "gross up" plaintiffs for excess taxes resulting from the AMT trap. Only three reported cases have addressed this gross up issue. In the only case involving federal law, the plaintiff was unsuccessful in arguing that he was entitled, under Title VII of the Civil Rights Act of 1964, to either a gross up award or an order requiring the defendant to indemnify him against the adverse tax consequences caused by the AMT trap. Porter v. United States Agency for Int'l Dev., 2003 U.S. Dist. LEXIS 21358 (D.D.C. 2003). However in two cases involving the application of state law, the plaintiff was awarded a gross up for adverse AMT consequences. Blaney v. Int'l Ass'n of Machinists and Aerospace Workers, Dist. No. 160, 55 P.3d 1208, 1214-18 (Wash. Ct. App. 2002), rev. granted 69 P.3d 875 (Wash. 2003) (applying the Washington Law Against Discrimination); Ferrante v. Sciaretta, 2003 N.J. Super. LEXIS 408, at *4 (N.J. Super. Ct. Law Div. 2003) (applying New Jersey's Laws Against Discrimination). In addition, some federal courts have ordered gross ups for adverse tax consequences (not involving the AMT) resulting from a lump sum backpay award. See O'Neill v. Sears, Roebuck \& Co., 108 F. Supp. 2 d 443 (E.D. Pa. 2000) (ordering gross up under the Age Discrimination in Employment Act); Sears v. Atchison, Topeka \& Santa Fe Ry., Co., 749 F.2d 1451 (10th Cir. 1984) (allowing gross 
trap lack sufficient political muscle.

In this Essay, I will not rehash the tax policy and doctrinal issues associated with the AMT trap. Rather, I will consider the ethical, fiduciary duty, and malpractice implications of the trap. Specifically, I will consider the duty of trial lawyers to advise their clients of the existence of the trap. I conclude that lawyers have both an ethical and legal duty to inform their clients about the trap at various junctures during litigation. Perhaps as a result of this duty (and the potential sanctions and liability exposure in the event of breach), the politically adept trial lawyers might be able to convince Congress to act responsibly and finally fix this mess. ${ }^{13}$

Part I of this Essay sets forth the mechanics of the AMT trap. Part II discusses two recent non-tax cases that have raised the ethical, fiduciary duty and malpractice implications of the trap. Part III analyzes these ethical issues, while Part IV addresses fiduciary duty and malpractice implications. Part V considers a loose end-what are the tax consequences to a plaintiff upon prevailing in a fiduciary duty/malpractice action against her former attorney?

\section{THE MEChanics OF THE AMT TRAP}

Assume that Paula settles an employment discrimination claim for $\$ 1,000,000$. Pursuant to a contingent fee agreement, $\$ 400,000$ of the proceeds go directly to her attorney, and Paula retains the remaining $\$ 600,000$.

In most areas of the country, Paula is required to include the full $\$ 1,000,000$ in her gross income and take a deduction for the attorney

up under Title VII). But see Dashnaw v. Pena, 12 F.3d 1112, 1116 (D.C. Cir. 1994), superseded on other grounds by regulation as stated in Rann v. Chao, 346 F.3d 192, 198 (D.C. Cir. 2003) (declining to order gross up under Title VII). If plaintiffs were clearly entitled to gross ups for adverse consequences resulting from the AMT trap, then plaintiffs would generally be unaffected by the trap, and the ethical, fiduciary duty and malpractice issues discussed in this Essay would not exist. However, the right of plaintiffs to such a gross up is uncertain at best under current law; therefore, this Essay assumes that such a gross up will not be awarded.

${ }^{13}$ Several bills have been proposed which would fix the AMT trap in discrimination cases, but they have not been enacted. See, e.g., the Civil Rights Tax Relief Act of 2003, S. 557, 108th Cong. (2003). Although these bills would solve the AMT problem in most cases, the problem would persist in other cases, such as employment related cases not involving discrimination. In addition, the bills would do more than just solve the AMT problem; they would exclude all compensatory damages received by victims of discrimination except for back-pay and front-pay components. See id. 
fee portion. $^{14}$ However, because the $\$ 400,000$ constitutes a miscellaneous itemized deduction, ${ }^{15}$ the deduction is impaired in various ways. $^{16}$ The most significant impairment is that, for AMT purposes, the $\$ 400,000$ is entirely non-deductible. ${ }^{17}$

14 The majority rule requiring full inclusion has been followed in the Federal, First, Second, Third, Fourth, Seventh, and Tenth Circuits. See Baylin v. United States, 43 F.3d 1451 (Fed. Cir. 1995); Alexander v. Internal Revenue Service, 72 F.3d 938 (1st Cir. 1995); Raymond v. United States, 2004 U.S. App. LEXIS 417 (2d Cir. 2004); O'Brien v. Commissioner, 319 F.2d 532 (3d Cir. 1963); Young v. Commissioner, 240 F.3d 369 (4th Cir. 2001); Kenseth v. Commissioner, 259 F.3d 881 (7th Cir. 2001); Hukkanen-Campell v. Commissioner, 274 F.3d 1312 (10th Cir. 2001), cert. denied, 535 U.S. 1056 (2002). The Ninth Circuit has also followed this rule in cases where the contingent fee agreement was governed by California or Alaska law, but has followed the minority rule in cases where the fee agreement was governed by Oregon law. Compare Benci-Woodward v. Commissioner, 219 F.3d 941 (9th Cir. 2000) (requiring full inclusion where fee agreement governed by California law), and Coady v. Commissioner, 213 F.3d 1187 (9th Cir. 2000), cert. denied, 532 U.S. 972 (2001) (requiring full inclusion where fee agreement governed by Alaska law), with Benaitis v. Commissioner, 340 F.3d 1074 (9th Cir. 2003) (following minority rule where fee agreement governed by Oregon law). The minority rule allowing the exclusion of the contingent fee portion of the award has been followed in the Fifth, Sixth, and Eleventh Circuits. See Cotnam v. Commissioner, 263 F.2d 119, 125 (5th Cir. 1959); Srivastava v. Commissioner, 220 F.3d 353, 364 (5th Cir. 2000); Estate of Clarks v. Commissioner, 202 F.3d 854 (6th Cir. 2000); Banks v. Commissioner, 345 F.3d 373 (6th Cir. 2003); Davis v. Commissioner, 210 F.3d 1346, 1347 (11th Cir. 2000); Foster v. United States, 249 F.3d 1275 (11th Cir. 2001). However, the basis for exclusion differed in these minority view cases, with some relying on peculiarities in state attorney lien law and others using a broader basis. See Polsky, supra note 3, at 74 n.83. It appears that the Fifth and Sixth Circuits allow exclusion regardless of state attorney lien law. Srivastava, 220 F.3d at 364; Banks, 345 F.3d at 384-86. At the same time the Eleventh Circuit would allow exclusion only if the relevant attorney lien law operated in a manner sufficiently similar to Alabama's. Davis, 210 F.3d at 1347; Foster, 249 F.3d at 1279-80. Professor Charles Davenport has suggested that the plaintiffs affected by the trap should argue that the attorney's fees are not properly analyzed as a deduction in the first place; rather, he argues that the expenses should be capitalized into the basis of the cause of action and applied as a basis-offset to the amount realized pursuant to the settlement or award. Charles Davenport, Why Tort Legal Fees Are Not Deductible, 97 TAX Notes 703 (Nov. 4, 2002); see also Charles Davenport, Capitalization of Legal Fees: Professor Davenport Responds, 97 TAX NOTES 1237 (Dec. 2, 2002). For a critique of Professor Davenport's capitalization argument see Brant J. Hellwig, Tax Treatment of Legal Fees: The Debate Continues, 97 TAx Notes 1235 (Dec. 2, 2002), and Brant J. Hellwig, Davenport's Capitalization Argument Fails to Convince, 98 TAX NOTES 433 (Jan. 20, 2003).

15 I.R.C. $\$ 67$.

${ }^{16}$ For a full discussion of the various impairments, see Polsky, supra note 3, at 64-67.

${ }^{17}$ See I.R.C. $\$ 56(\mathrm{~b})(1)(\mathrm{A})(\mathrm{i})$. 
As a result of this AMT treatment, assuming for simplicity purposes that Paula has no deductions or any other income, Paula would owe tax of $\$ 276,500$. $^{18}$ On the other hand, if Paula were entitled to exclude the attorney fee portion of the award (and thereby include only $\$ 600,000$ in gross income), Paula would owe tax of only $\$ 205,985$. The AMT trap thus costs Paula $\$ 70,515$. As a result, Paula's after-tax recovery from the litigation is reduced from $\$ 394,015$ to $\$ 323,500$. Accordingly, Paula's effective tax rate on her ultimate recovery is increased from $34.33 \%$ to $46.08 \%$.

The effect of the AMT trap becomes even more significant as the ratio of Paula's attorney's fees (and costs) to the total settlement amount increases. For example, assume that, because of significant litigation costs, $\$ 800,000$ of the $\$ 1,000,000$ settlement, rather than $\$ 400,000$, go to Paula's attorney. As a result, the AMT trap would cause Paula to owe $\$ 276,500$ in taxes, or $\$ 76,500$ more than her recovery. In such a case, Paula's effective tax rate on her recovery is a preposterous $138.25 \%$.

\section{Two RECENT NON-TAX CASES}

The legal ethics and malpractice implications of the AMT trap have been raised in two recent non-tax cases. In Jalali $v$. Root, a California state appellate decision, an employment discrimination plaintiff alleged that her lawyer committed malpractice when he gave her bad tax advice. ${ }^{20}$ When the plaintiff received a settlement offer of $\$ 2.75$ million, the lawyer told her that her tax liability resulting from

${ }^{18}$ For all tax computations, it is assumed that the settlement was received in 2002, that Paula's taxable year ended December 31, 2002, that Paula has no dependents, and that she is unmarried.

19 In this case, Paula's tax liability attributable to the settlement would be greater than the amount of her ultimate recovery. None of the reported tax cases concerning the AMT trap appear to have involved such a scenario in which a successful plaintiff ends up paying taxes out of her pocket, and it is unclear how the Internal Revenue Service (Service) would respond to such a scenario. Perhaps the Service would make the administrative decision not to seek to recover taxes caused by the AMT trap in excess of the plaintiff's pre-tax recovery. However, there is anecdotal evidence in the popular press that the Service is in fact seeking the full amount of taxes owed resulting from the tax trap. See Adam Liptak, Tax Bill Exceeds Award to Officer in Sex Bias Suit, N.Y. TIMES, Aug. 11, 2002, § 1, at 18 (describing a case of a successful discrimination plaintiff owing taxes of approximately $\$ 100,000$ more than her litigation proceeds after payment of attorney's fees and costs).

201 Cal. Rptr. 3d 689 (Cal. Ct. App. 4th 2003). 
the settlement would be "forty percent of [her] share." 21 To back up this tax advice, the attorney told the plaintiff, "[ $t]$ his is my field. I know what taxes are for discrimination cases."22 However, because of the AMT trap, the attorney's advice was erroneous; in fact, the plaintiff ended up owing $\$ 310,000$ more in taxes than the attorney had represented. $^{23}$

The plaintiff sued to recover the difference, alleging that the attorney's erroneous tax advice constituted legal malpractice. ${ }^{24}$ At trial, the jury agreed and awarded the plaintiff the $\$ 310,000$ difference. ${ }^{25}$

On appeal, the court specifically did "not address the general question of whether personal injury lawyers have any duty, under normal circumstances, to accurately apprise their clients of the tax implications of any recovery they might obtain for their clients," because in the case at hand the attorney "held himself out as particularly competent to give tax advice in the context of recoveries in discrimination cases." 26 Nevertheless, the court held for the attorney because the plaintiff had failed to provide evidence that the erroneous advice had caused the plaintiff any damages. ${ }^{27}$ According to the appellate court, in order to prevail, the plaintiff was required to prove that, but for the erroneous advice, the plaintiff would have turned down the $\$ 2.75$ million offer and ultimately received a larger recovery. ${ }^{28}$ Because the plaintiff failed to "show that she could have done better if she hadn't accepted the settlement," the court entered judgment for the attorney. ${ }^{29}$

Another recent case is the Seventh Circuit's decision in Shott v. Rush-Presbyterian-St. Luke's Medical Center. ${ }^{30}$ In Shott, an employment discrimination plaintiff received a jury award of $\$ 60,000$ in compensatory damages under the Americans with Disabilities Act

${ }^{21}$ Id. at 692 .

22 Id. at 693.

${ }^{23} I d$. at 692 . The plaintiff still ultimately ended up with an after-tax recovery of roughly $\$ 700,000$, though she had expected to end up with about $\$ 1,000,000$. Id. at 696.

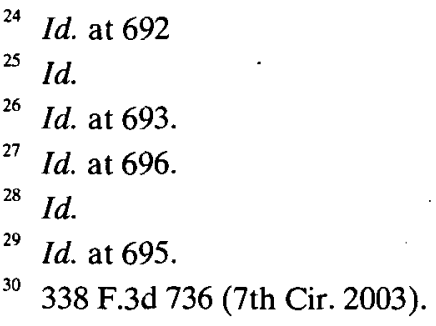


(ADA). ${ }^{31}$ The plaintiff thereafter filed a petition for attorney's fees under the ADA, and was awarded approximately $\$ 430,000$ in attorney's fees and costs. ${ }^{32}$

The defendant challenged the award based on a pre-trial settlement offer by the defendant that was rejected by the plaintiff. ${ }^{33}$ The Seventh Circuit had previously held that, in awarding attorney's fees to a prevailing plaintiff under the ADA, fees accumulated after the plaintiff rejects a "substantial offer" could be disregarded. ${ }^{34}$ An offer is substantial for this purpose if "the offered amount appears to be roughly equal to or more than the total damages recovered by the prevailing party." 35

The pre-trial offer by the defendant was to allow the plaintiff to change job positions and remain at her current salary for the remainder of the year. ${ }^{36}$ The offer did not include any payments for damages, attorney's fees, or costs. ${ }^{37}$ The defendant argued that, because of the AMT trap, this pre-trial offer was better for the plaintiff than the jury award plus the attorney's fees. ${ }^{38}$ According to the defendant, as a result of the judgment, the plaintiff would owe taxes of $\$ 125,644$, or $\$ 65,644$ more than the $\$ 60,000$ she actually received. In other words, using after-tax dollars, the plaintiff would have been better off settling for zero dollars rather than winning the trial and owing $\$ 65,644$ out-of-pocket.

The court rejected the defendant's argument on evidentiary grounds, emphasizing that "none of the information upon which [the defendant] relies in purporting to calculate [the plaintiff's] tax liability is in the record." 39 More importantly, the court suggested in dicta that, for purposes of determining whether a rejected offer is substantial, only pre-tax dollars should be considered:

Furthermore, though we need not decide this issue now, we doubt that it would be appropriate for this court to establish a precedent wherein attorneys would be required to know the tax status of their clients before accepting or rejecting a

31 Id. at 739.

${ }^{32}$ Id.

${ }^{33}$ Id. at 743 .

34 Moriarty v. Svec, 233 F.3d 955, 967 (7th Cir. 2000).

${ }^{35}$ Id.

36 Shott, 338 F.3d at 743.

37 Id.

${ }^{38}$ Id. at 744 .

Id. 
settlement offer ${ }^{40}$ or wherein courts would routinely have to delve into the tax records of the parties to determine an appropriate fee award... [F]ee litigation already places a "heavy burden" on the federal courts; adding a requirement to calculate the tax status of the parties would only increase that burden. ${ }^{41}$

The italicized language above shows that the court was aware of the potential malpractice and ethical issues created by the tax trap. At the time of the settlement offer, should the plaintiff's attorney have advised his client of the adverse consequences resulting from the AMT trap? Should this tax advice have been given at the time the plaintiff chose to file her petition for statutory attorney's fees? Should it have been given at the inception of the case? These issues and others are discussed below.

\section{ETHICAL ISSUES}

This Part examines whether the tax trap implicates ethical issues. For purposes of the analysis of this part, it is assumed that the attorney is aware of the tax trap and the fact that it may subject the client to an extremely high rate of tax (possibly in excess of 100 percent) on the client's net recovery. Subpart A considers potential conflicts of interest for a lawyer with knowledge, while Subpart B discusses such a lawyer's ethical obligations to inform the client of the effect of the trap.

\section{A. Conflict of Interest}

Under the ABA Model Rules, a conflict of interest exists if "there is a significant risk that the representation of [a client] will be materially limited... by a personal interest of the lawyer.," ${ }^{42}$ The conflict that arises from the tax trap may occur at various junctures during the attorney-client relationship. In each of these cases, it is in the attorney's personal best interests not to disclose the existence of the tax trap, while it is in the client's best interests to consider the

40 The Shott court's reluctance to place a duty on trial lawyers with regard to their client's tax issues is reminiscent of the California Supreme Court's holding in Lucas v. Hamm, 56 Cal. 2d 583 (1961), that as a matter of law, it is not negligent for a lawyer to misunderstand the rule against perpetuities.

41 Shott, 338 F.3d at 744 (emphasis added).

42 Model Rules of Prof'L Conduct R. 1.7(a) (2003). 
effect of the trap in making crucial litigation decisions.

\section{Juncture \#1: Taking the Case}

Assume that a client approaches a lawyer with a solid employment discrimination or civil rights case that, if successful, would result in a small award of damages relative to the probable amount of attorney's fees and costs that it will generate (a "low value/high fee case"). Such a case is an ideal situation for a huge AMT trap, because the ratio of attorney's fees to the overall recovery will be quite high. As a result, a potential conflict arises between the attorney, who wants to take the case and obtain his fees, and the client, who might be better off avoiding litigation because the AMT trap may consume the entire recovery (and, possibly, money out of her pocket).

Even in cases in which the legal fees will not represent such a large part of the overall recovery, a plaintiff may decide to avoid litigation if she is aware of the tax trap. If the plaintiff is conflicted about instigating the litigation because, for example, she is concerned about the distraction and stress of litigation, the extra tax burden caused by the tax trap may be enough to cause the plaintiff to drop the case to the detriment of the attorney's personal financial interests.

\section{Juncture \#2: Settlement Offers}

Now assume that, in another low value/high fee case, a very early lowball settlement offer is made by the defendant. Once again, a conflict arises. The attorney would be better off if the client rejects the offer, thereby maximizing his fee recovery. However, the client may be better off accepting the lowball offer, thereby possibly avoiding the AMT trap altogether. ${ }^{43}$ In analyzing the merits of the settlement offer, an informed client would consider the possibility that the trap may cause her to pay taxes out of her pocket or the possibility that the tax trap might consume a large portion of a subsequent larger settlement. Therefore, if the client is fully aware of the tax trap, the likelihood is greater that she will accept the lowball offer to the detriment of the attorney's personal financial interests.

${ }^{43}$ Accepting an early lowball offer may avoid implicating the AMT trap for two reasons. First, the settlement may be too small to trigger the AMT. Second, if the claim triggered a fee-shifting statute, an early settlement will avoid the incurrence of a significant amount of attorney's fees (when viewed in relation to the plaintiff's net recovery), thereby avoiding the tax trap. 


\section{Juncture \#3: The Motion for Fees}

In many situations in which the tax trap may arise, there is a statute that allows a victorious plaintiff to petition the court to award attorney's fees. $^{44}$ In a typical case, a contingent fee agreement provides that the attorney will receive the greater of (a) some percentage of the overall recovery (possibly including court-awarded attorney's fees) or (b) the amount of court-awarded attorney's fees. In some cases in which (b) would be higher than (a), it actually may be in the client's best interests not to petition for attorney's fees. ${ }^{45}$ Of course, this is in conflict with the personal financial interests of the attorney, who wants to maximize his fees.

Take the Shott case, for example. If the plaintiff had waived the right to petition for fees, the attorney would have taken his percentage share of the $\$ 60,000$ damages and the plaintiff would have avoided the tax trap. ${ }^{46}$ However, by petitioning for fees, the plaintiff has put herself in a position to owe $\$ 65,644$ more in taxes than she recovers.

It would appear that the solution under the ABA Model Rules is for the attorney to advise the client of the existence and effect of the AMT trap and of the potential conflict, and to obtain informed consent in writing to continue the representation notwithstanding the conflict, at each of these three critical junctures. ${ }^{47}$ It would probably also be prudent for the attorney to strongly advise the client to seek

${ }^{44}$ See, e.g., 42 U.S.C. $\$ 12205$ (2003) (providing for court-awarded attorney's fees to a prevailing party under the ADA).

${ }^{45}$ It is clear that the decision to petition for fees rests with the client, not the attorney. See id. (providing for fees to the prevailing party); Sinyard, 268 F.3d at 759 (recognizing that fee awards belong to the client, not the lawyer, under fee shifting statutes).

${ }^{46}$ The plaintiff would have avoided the tax trap because, regardless of the attorney's share of the $\$ 60,000$ recovery, the AMT would not have been triggered at such a low level of gross income.

47 Model Rules OF PROF'L CONDUCT R. 1.7(b) (2003) (providing that certain conflicts of interest may be waived by the client through informed consent); id. R. 1.0(e) (defining "informed consent" as consent "after the lawyer has communicated adequate information and explanation about the material risks of and reasonably available alternatives to the proposed course of conduct"). Certain conflicts, those which inherently prevent competent and diligent representation, cannot be waived. Id. R. $1.7 \mathrm{cmt} .15$ (2003). However, the AMT trap probably does not create such a nonconsentable conflict, because the interests of the client should be adequately protected with informed consent. Id. Furthermore, if the trap is deemed to create a nonconsentable conflict, it might be impossible for the client to obtain representation in the litigation. 
independent tax advice from a tax professional. ${ }^{48}$

In the context of Juncture \#3 (the decision to petition for statutory fees), the attorney might also consider restructuring the contingent fee agreement to ensure that the client will not be in a worse after-tax position after receiving court-awarded fees than before. This could be done by reapportioning the total recovery between lawyer and client to ensure that client receives at least as many after-tax dollars as she would have in the absence of the motion for fees. Of course, the attorney may hesitate to offer such a restructuring, which effectively takes dollars out of his pocket and puts them in the government's coffers.

\section{B. Keeping the Client Reasonably Informed}

ABA Model Rule 1.4(b) requires a lawyer to "explain a matter to the extent reasonably necessary to permit the client to make informed decisions regarding the representation." 49 Pursuant to this duty, the lawyer must explain the potential benefits and burdens that may result from a particular course of action, so that the client has "sufficient information to participate intelligently in decisions concerning the objectives of the representation."

At all three of the various junctures identified above (i.e., initiating the litigation, considering settlement offers, and deciding whether to petition for fees), a client must be informed of the existence and effect of the AMT trap in order to appreciate fully the risks and rewards of potential courses of action. For example, in the context of deciding whether to initiate litigation, the client should be apprised of the risk that the AMT trap may reduce substantially the amount of her after-tax recovery and the risk that she may be forced to pay taxes attributable to the litigation in excess of her ultimate recovery. Only after considering these risks can the client make an intelligent decision about whether to undertake litigation.

${ }^{48} C f$. In Re Conduct of Bishop, 297 Or. 479, 487 (1984) (holding that, where attorney enters into business transaction with client, attorney must advise client to seek independent counsel); John S. Dzienkowski \& Robert J. Peroni, The Decline in Lawyer Independence: Lawyer Equity Investments in Clients, 81 TEX. L. REV. 405, 507-09 (contending that "if law firms desire to invest in their clients, they should require that their clients seek the advice of independent counsel before proceeding with the arrangement").

${ }^{49}$ MOdel Rules OF Prof'L CONDUCT R. 1.4(b) (2003).

${ }^{50}$ Id. 1.4(b) cmt. 5; see also In re Winkel, 577 N.W.2d 9, 11 (Wis. 1998) (attorney's failure to advise client about risk of criminal prosecution from a course of action constituted an ethical breach). 


\section{FIDUCIARY DUTY \& MALPRACTICE IMPLICATIONS}

The ethical rules discussed above require a lawyer with knowledge to advise his clients of the AMT trap's effects at certain critical junctures during the litigation. This Part considers the fiduciary duty and malpractice implications of the trap. Although courts have consistently held that a legal ethics violation is not by itself a breach of fiduciary duty or the appropriate standard of care, ${ }^{51}$ courts have generally found that an ethics violation may be used as evidence in legal actions against attorneys. ${ }^{52}$

\section{A. The Fiduciary Duties of a Lawyer with Knowledge}

An agent has a fiduciary duty "to treat his principal with the utmost candor, rectitude, care, loyalty and good faith - in fact to treat the principal as well as the agent would treat himself." ${ }^{53}$ In the

51 See, e.g., Astarte, Inc. v. Pac. Indus. Sys., Inc., 865 F. Supp. 693, 706 (D. Colo. 1994); Coleman v. Hicks, 433 S.E.2d 621, 623 (Ga. Ct. App. 1993); Nagy v. Beckley, 578 N.E.2d 1134, 1136 (Ill. App. Ct. 1991); Maritrans G.P. Inc. v. Pepper, Hamilton \& Scheetz, 602 A.2d 1277, 1284 (Pa. 1992); see also Model Rules of Prof'L Conduct pmbl. I 20. (2003) ("Violation of a Rule should not itself give rise to a cause of action against a lawyer...").

52 See, e.g., RTC Mortgage Trust 1994 N-1 v. Fid. Nat'l Title Ins. Co., 58 F. Supp. 2d 503, 525 (D.N.J. 1999); Griffith v. Taylor, 937 P.2d 297, 301 (Alaska 1997); Mirabito v. Liccardo, 5 Cal. Rptr. 2d 571, 573 (Ct. App. 1992); Waldman v. Levine, 544 A.2d 683, 690-91 (D.C. 1988); Allen v. Lefkoff, Duncan, Grimes \& Dermer, P.C., 453 S.E.2d 719, 721 (Ga. 1995); Mayol v. Summers, Watson \& Kimpel, 585 N.E.2d 1176, 1186 (Ill. App. Ct. 1992); Sargent v. Buckley, 697 A.2d 1272, 1275 (Me. 1997); Fishman v. Brooks, 487 N.E.2d 1377, 1381 (Mass. 1986); Welsh v. Case, 43 P.3d 445, 452 (Or. Ct. App. 2002); McNair v. Rainsford, 499 S.E.2d 488, 494 (S.C. Ct. App. 1998) (each holding that an ethical violation may be used as evidence of a lawyer's duty to his client). See also Hart v. Comerica Bank, 957 F. Supp. 958, 981 (E.D. Mich. 1997) (holding that an ethical violation creates a rebuttable presumption that lawyer committed malpractice). But see Hizey v. Carpenter, 830 P.2d 646, 654 (Wash. 1992) (holding that, although an expert could consider ethics rules in developing an opinion about standard of care, ethics rules are not admissible in action against attorney); Lazy Seven Coal Sales Inc. v. Stone \& Hinds, P.C., 813 S.W. 2d 400, 407 (Tenn. 1991) (same); Orsini v. Larry Moyer Trucking, Inc., 833 S.W.2d 366, 369 (Ark. 1992) (holding that an ethics violation is simply irrelevant in action against attorney and may not be used for any purpose); Harrington v. Pailthorp, 841 P.2d 1258, 1262 (Wash. Ct. App. 1992) (same); Wilbourn v. Stennett, Wilkinson \& Ward, 687 So.2d 1205, 1215-16 (Miss. 1996) (same).

${ }^{53}$ Burdett v. Miller, 957 F.2d 1375, 1381 (7th Cir. 1992) (Posner, J.). 
context of an attorney-client relationship, a lawyer owes a fiduciary duty "to represent the client with undivided loyalty ... and to disclose any material matters infringing upon th[is] obligation[]." ${ }^{14}$ As explained above, the AMT trap may infringe upon the lawyer's undivided loyalty to the client, particularly in low value/high fee cases. As a result of the trap, an attorney's personal best interests in maximizing his fee recovery may be at odds with the client's best interests of avoiding the pernicious effects of the trap. Therefore, in cases in which this conflict could arise, an attorney with knowledge has a fiduciary duty to advise the client of the trap and its effects, as well as the conflict of interest it creates. ${ }^{55}$

An attorney who fails to advise the client of this conflict is liable for damages consisting of two components. First, the attorney is liable to the extent the failure to advise of the AMT trap has caused the client actual damages. This causation issue is discussed below in the discussion of legal malpractice law.

Second, even in the absence of actual damages, the attorney may be required to forfeit all or a part of the fee paid by the client. As a result, unlike in the malpractice context, ${ }^{56}$ a lawyer may be liable for damages in a fiduciary action even if the client cannot show that the lawyer's breach actually caused any harm. ${ }^{57}$ The amount of the fee

542 Ronald E. Mallen \& JefFrey M. SMith, Legal Malpractice $\S 14.1$, at 227 (4th ed. 1996).

55 Although the scope of fiduciary and legal malpractice law overlap significantly, see Meredith J. Duncan, Legal Malpractice by Any Other Name: Why a Breach of Fiduciary Duty Claim Does Not Smell as Sweet, 34 WAKE FOREST L. REV. 1137, 1162-67 (1999), I limit my analysis of fiduciary law to cases in which a lawyer has knowledge of the AMT trap and my analysis of malpractice law to cases in which a lawyer lacks such knowledge.

56 See infra Part IV.B.2.

57 See Duncan, supra note 55, at 1160-61. The Supreme Court of Texas recently explained the policy behind allowing damages for fiduciary duty violations even in the absence of actual harm:

It is the agent's disloyalty, not any resulting harm, that violates the fiduciary relationship and thus impairs the basis for compensation. An agent's compensation is not only for specific results but also for loyalty. Removing the disincentive of forfeiture except when harm results would prompt an agent to attempt to calculate whether particular conduct, though disloyal to the principal, might nevertheless be harmless to the principal and profitable to the agent. The main purpose of forfeiture is not to compensate an injured principal, even though it may have that effect. Rather, the central purpose of the equitable remedy of forfeiture is to protect relationships of trust by discouraging agents' disloyalty. 
forfeiture (i.e., whether full or partial and, if partial, what amount) depends on the facts and circumstances of the breach, including "the gravity and timing of the violation, its willfulness, its effect on the value of the lawyer's work for the client, any other threatened or actual harm to the client, and the adequacy of other remedies."

\section{B. Malpractice Implications}

The discussion thus far has assumed that a lawyer has knowledge of the trap and has concluded that such a lawyer has both an ethical and fiduciary duty to advise his client of the trap. This subpart considers the case of the "unknowing lawyer," one who is simply unaware of the trap. Therefore, unlike the previous discussion, which considered the duty of loyalty to the client, this subpart considers the duty of care and asks the question: "Does a trial lawyer have a duty to know about and understand the AMT trap and its potential effect on plaintiffs?" Or, to put the matter a bit differently: "Is it negligent for a trial lawyer to be unaware of the tax trap?"

\section{The Standard of Care}

In representing a client, an "attorney should exercise the skill and knowledge ordinarily possessed by attorneys under similar circumstances." 59 Accordingly, the key issue is whether attorneys who prosecute employment discrimination and civil rights cases ordinarily appreciate the existence and effect of the AMT trap. In general, plaintiffs attempt to prove standard of care by introducing expert testimony by practitioners in the same field as the defendant lawyer. ${ }^{60}$ Consequently, a plaintiff subject to the AMT trap would attempt to introduce expert testimony that most trial lawyers litigating cases such as the plaintiff's are fully aware of the existence of the trap. The standard of care issue is a question of fact, and ultimately will be decided by a jury.

Even if it is proven that most similarly situated lawyers know about the AMT trap, the defendant lawyer may argue that, as a

Burrow v. Arce, 997 S.W.2d 229, 238 (Tex. 1999).

58 Restatement (ThiRd) OF LAw Governing LAwYERs $\$ 49$ (Proposed Final Draft No. 1, 1996); see also Burrow, 997 S.W.2d at 241-42 (adopting the restatement's standard).

59 MALLEN \& SMITH, supra note 54, $\S 18.2$, at 551 (emphasis in original omitted). See generally id. $\S 18.3$ (discussing the bounds of competence).

${ }^{60}$ Id. $\$ 18.4$. 
matter of law, he simply has no duty to know about the intricacies of the Code. The defendant would argue that, in agreeing to prosecute the client's claim, his obligation was only to litigate the cause of action and provide the client with the best possible result, without consideration of tax consequences. The defendant might point out that he never explicitly indicated or suggested that he would render tax advice and argue that personal income tax issues are inherently personal-or to state the argument more bluntly, the plaintiff's personal tax issues are her problems, not the attorney's. In fact, the contingent fee agreement might expressly carve out any obligation to render tax advice. ${ }^{61}$ As a result, the defendant would argue, tax issues were outside of the agreed scope of his representation.

This argument should fail for two reasons. First, there is no reason to define a trial lawyer's duty so narrowly. The negative tax consequences resulting from the AMT trap constitute adverse legal consequences arising directly from the litigation overseen by the attorney. As a result, it is hard to see how advice relating to these tax consequences can be outside the scope of representation.

Second, even if one accepts the notion that tax consequences are outside of the explicit scope of the representation, courts have generally held that a lawyer may have "peripheral duties" to his client. For example, in Nichols $v$. Keller, a California appellate court held that a lawyer handling a client's worker's compensation claim may have a duty to advise the client regarding other claims against third parties $^{63}$ even if the lawyer expressly limits the scope of representation:

61 Although the ABA Model Rules allow a lawyer to limit the scope of representation, the limitation must "be reasonable under the circumstances" and the client must agree to the limitation after giving informed consent. MODEL RULES OF PROF'L CONDUCT R. 1.2(c) (2003).

${ }^{62}$ The Shott court, though it did not decide the issue, appeared to be amenable to this argument. In dicta, it "doubt[ed] that it would be appropriate for this court to establish a precedent wherein attorneys would be required to know the tax status of their clients before accepting or rejecting a settlement offer." 338 F.3d at 744 . However, the Shott court misunderstood the nature of the AMT trap. Imposing a duty on employment discrimination and civil rights plaintiffs lawyers would not require them "to know the tax status of their clients." Id. All they would need to know was that the AMT trap exists, that it may adversely affect their clients (particularly in low value/high fee cases), and that their clients should seek independent tax advice at critical junctures.

63 For example, the client may have tort claims against persons other than the employer for negligence, medical malpractice, or products liability. 
Generally speaking, a workers' compensation attorney should be able to limit the retention to the compensation claim if the client is cautioned (1) there may be other remedies which the attorney will not investigate, and (2) other counsel should be consulted on such matters. However, even when a retention is expressly limited, the attorney may still have a duty to alert the client to legal problems which are reasonably apparent, even though they fall outside the scope of the retention. The rationale is that, as between the lay client and the attorney, the latter is more qualified to recognize and analyze the client's legal needs. The attorney need not represent the client on such matters. Nevertheless, the attorney should inform the client of the limitations of the attorney's representation and of the possible need for other counsel. ${ }^{64}$

The reasoning by the Nichols court applies equally in the context of the AMT trap. As between the lay client and the attorney, the attorney is more qualified to know about, and appreciate the draconian effects of, the trap. As a result, the argument that no duty exists as a matter of law for a trial lawyer to advise his client of the AMT trap is not persuasive. ${ }^{65}$

\section{Causation \& Damages}

Unlike in a breach of fiduciary duty action, a client must show that the lawyer's malpractice caused actual damages in order to recover. Therefore, as the Jalali court held, the client must show that, had the appropriate information about the AMT trap been conveyed, the client would have done better. ${ }^{66}$

In the AMT trap context, causation might be very easy to prove in

${ }^{64} 19$ Cal. Rptr. 2d 601, 608 (Cal. Ct. App. 1993).

${ }^{65}$ See also Int'l Tele-Marine Corp. v. Malone \& Assocs., 845 F. Supp. 1427, 1433 (D. Colo. 1994) ("[E]ven though an attorney can limit the scope of the representation, one cannot disregard circumstances which provide reasonable notice that the client may have legal problems or remedies which fall outside the scope of the undertaking."); Daugherty v. Runner, 581 S.W.2d 12, 17 (Ky. Ct. App. 1978) (unwilling to hold that a personal injury lawyer has "absolutely no duties to his client with regard to a medical malpractice action simply because the written contract did not specifically mention a malpractice suit," because "[ $t] 0$ do so would require the client, presumably a layman who is unskilled in the law, to recognize for himself all potential legal remedies").

${ }^{66} 1$ Cal. Rptr. 3d at 699-700, as modified on denial of reh'g, 2003 WL 21536965 (Cal. Ct. App. 2003). 
a low value/high fee case in which the client ends up owing more in taxes than her recovery (net of attorney's fees). Assume that, as a result of the AMT trap, the client ends up owing $\$ 100,000$ in taxes out of her pocket (i.e., in excess of net recovery). In such a case, the client would need to show that, had the information about the AMT trap been given, she would have decided not to litigate the case. If she can prove this, she would recover the $\$ 100,000$ of taxes she was forced to pay out-of-pocket. ${ }^{67}$

However, in cases in which the AMT trap merely increases the tax rate applied to the client's recovery to a rate less than one hundred percent so that the client does end up with some after-tax recovery, causation is much harder, if not impossible, to prove. For example, in the Jalali case, the court held that, in order for Jalali to prevail, she would have to prove that, had the attorney correctly apprised her of the tax consequences, she would have (1) rejected the $\$ 2.75$ million settlement offer, and (2) ultimately settled, or received a collectible judgment, for an amount greater than $\$ 2.75$ million. ${ }^{68}$ In essence, in addition to proving malpractice, she would have to try the underlying case and show that she could have done better. Absent some evidence that the trial lawyer's conduct fell below the standard of care in some other respect, there is no reason to think that, in cases where the effective tax rate is less than one hundred percent, the client could have done better had she been aware of the AMT trap.

\section{A Loose End-Tax Treatment of Malpractice Awards}

Assume that the plaintiff in Jalali had prevailed on appeal and ultimately recovered $\$ 310,000$ from her former attorney (or the attorney's malpractice insurance company). Would this $\$ 310,000$ be taxable to Jalali? ${ }^{69}$ This section considers this question.

In arguing that this amount is excluded from gross income, Jalali would make two arguments. The first is that the amount represents a

${ }^{67}$ It may be difficult for the plaintiff to prove that, had she been fully aware of the tax trap, she would not have litigated the case. After all, at the time she would decide whether or not to go forward, she would not know the amount of litigation expenses. However, in cases in which the compensatory damages will likely be nominal, it may be fairly easy for the plaintiff to show that the risk of implicating the tax trap would have been sufficient to cause her to drop the case.

68 Jalali, 1 Cal. Rptr. 3d at 696.

${ }^{69}$ Ironically, if this amount is taxable, Jalali may be subject to the AMT trap again, depending on the amount she must pay to her own attorney in the malpractice claim. 
tax-free recovery of capital under the 1939 case of Clark $v$. Commissioner. ${ }^{70}$ The second is that the amount represents a refund of attorney's fees previously paid to the attorney, which did not give rise to any tax benefit and are thus excluded from gross income by virtue of the exclusionary aspect of the tax benefit rule in section 111(a).

\section{A. The Clark Case}

In Clark, the taxpayer paid an excessive amount of federal taxes because his tax counsel negligently failed to advise him to file a separate return, rather than a joint return with his wife. This negligence caused the taxpayer to pay approximately $\$ 20,000$ more in federal taxes than he would have paid had he filed a separate return. The taxpayer ultimately recovered this excess from his tax counsel, and the issue in Clark was whether this amount was required to be included in the taxpayer's gross income. In a brief and conclusory opinion, the Board of Tax Appeals held that the taxpayer could exclude the excess tax payment because it represented "compensation for a loss which impaired [the taxpayer's] capital.",71

On its face, Jalali's $\$ 310,000$ hypothetical recovery is similar to Clark's recovery. Each is based on a lawyer's negligence and its impact on the taxpayer's federal tax liability. However, these cases are distinguishable. In Clark, the taxpayer truly paid too much tax because of negligent advice-simply by electing to file a separate return, Clark's tax liability would have been reduced. . However, Jalali could do nothing to reduce her tax liability - there was no way to structure the settlement to avoid the AMT trap. Simply put, Jalali paid no excess taxes.

Although the analogy to Clark is not strong with respect to Jalali's hypothetical recovery, the analogy is much stronger with regard to a case in which the taxpayer ends up owing more in taxes than her recovery net of attorney's fees. For example, assume that a plaintiff ends up owing $\$ 100,000$ in taxes in excess of her net recovery. If the plaintiff recovers this $\$ 100,000$ excess from her lawyer, the Clark rule of exclusion may be applicable. In this case, the plaintiff arguably paid excess taxes, since she could have avoided the $\$ 100,000$ tax liability simply by not prosecuting the case. Like the taxpayer in Clark, the plaintiff ends up owing too much tax because of her counsel's negligent advice. 
However, it is unclear whether the Clark rule should be interpreted so broadly. Professor Lawrence Zelenak has argued that the rule of exclusion in Clark should be limited to cases in which the taxpayer paid too much tax based on the non-tax facts of the taxpayer's transactions. ${ }^{72}$ While Clark overpaid his taxes based on the non-tax facts due to a failure to make an election for tax purposes, the plaintiff in the instant hypothetical paid the correct amount of tax based on the non-tax facts. The Service, in a series of recent private letter rulings, appears to agree with Professor Zelenak's conclusion, ruling that exclusion under Clark is warranted only where taxpayers "pay more than their minimum proper federal income tax liabilities based on the underlying transactions for the years in question."73 Under this view, Clark's rule of exclusion would not apply even in cases in which the AMT trap caused the plaintiff to owe more in tax than her net recovery.

\section{B. The Tax Benefit Rule}

In addition to the unconvincing Clark argument, a fiduciary duty/malpractice plaintiff could argue that the damages she received represent a refund of attorney's fees previously paid and, as a result, that the damages are excluded from gross income pursuant to the

72 Lawrence Zelenak, The Taxation of Tax Indemnity Payments: Recovery of Capital and the Contours of Gross Income, 46 TAX L. REv. 381, 397-03 (1991).

${ }^{73}$ Priv. Ltr. Rul. 97-43-034 (July 28, 1997); Priv. Ltr. Rul. 97-43-035 (July 28, 1997). See also Priv. Ltr. Rul. 97-28-052 (Apr. 16 1997) (ruling that Clark applies only to cases in which a mistake causes "taxpayers to pay more than their minimum proper federal income tax liabilities based on the underlying transactions for the years in question"); Priv. Ltr. Rul. 98-33-007 (May 13, 1998) (same); Priv. Ltr. Rul. 2003-28033 (Apr. 8, 2003) (applying Clark to case in which taxpayer had paid an amount of tax greater than that which was required to be paid as a result of employer's erroneous classification, because the taxpayer had paid "more than his minimum proper federal tax liability"). However, courts have sometimes suggested that Clark might not be interpreted so narrowly. See Centex Corp. v. United States, $55 \mathrm{Fed}$. Cl. $381,388-89$ (2003) (concluding that government's reimbursement of taxpayer's tax benefits lost due to federal legislation that breached the government's contractual obligations to taxpayer would be excluded from taxpayer's gross income); Concord Instruments Corp. v. Commissioner, 67 T.C.M. (CCH) 3036 (1994) (holding that payment from taxpayer's former attorney resulting from attorney's failure to timely appeal adverse Tax Court judgment was excluded from taxpayer's gross income under Clark). For a discussion of these two cases, see Burgess J.W. Raby \& William L. Raby, Excludability of Tax Loss Reimbursements, 100 TAX NOTES 1689 (Sept. 29, 2003). 
exclusionary component of the tax benefit rule in section $111(\mathrm{a}) .^{74}$ Section 111(a) provides that an exclusion for a "recovery of any amount deducted in any prior taxable year to the extent such amount did not reduce the amount of [income] tax" owed in such prior taxable year.

As the Supreme Court has explained, the tax benefit rule was designed to mitigate the potentially harsh effects of the tax system's annual accounting principle:

An annual accounting system is a practical necessity if the federal income tax is to produce revenue ascertainable and payable at regular intervals. Nevertheless, strict adherence to an annual accounting system would create transactional inequities. For instance, if a taxpayer held a note that became apparently uncollectible early in the taxable year, but the debtor made an unexpected financial recovery before the close of the year and paid the debt, the transaction would have no tax consequences. If, however, the debtor's financial recovery and the resulting repayment took place after the close of the taxable year, the taxpayer would have a deduction for the apparently bad debt in the first year under Section 166(a) of the Code. Without the tax benefit rule, the repayment in the second year, representing a return of capital, would not be taxable. The second transaction, then, although economically identical to the first, could, because of the differences in accounting, yield drastically different tax consequences. $^{75}$

The tax benefit rule would generally require that the repayment in the second year be included in income, ${ }^{76}$ thereby "achiev[ing] rough transactional parity in tax." However, if the taxpayer realized no

${ }^{74}$ See Patricia D. White, An Essay on the Conceptual Foundations of the Tax Benefit Rule, 82 Mich. L. REV. 486, 488 (1983) (describing the inclusionary and exclusionary components of the tax benefit rule).

${ }^{75}$ Hillsboro Nat'l Bank v. Commissioner, 460 U.S. 370, 377 (1983) (citations omitted).

76 I.R.C. $\$ 111(\mathrm{a})$.

$n$ Hillsboro, 460 U.S. at 383 . The transactional parity is "rough" primarily because the taxpayer's marginal tax rates could be different between years one and two. See id. at 380 n.12. Even with stable marginal tax rates, the time value of money would prevent perfect transactional equivalence under section 111(a) because the amount included in year two is not adjusted to reflect the time value of money benefit the taxpayer received by taking the earlier deduction. 
benefit from the deduction in year one, the exclusionary aspect of the tax benefit rule would, consistent with this notion of transactional parity, allow the taxpayer to exclude the repayment in year two from gross income.

Turning to the application of the tax benefit rule to a successful fiduciary duty/malpractice claimant, assume that a claimant is paid $\$ 300,000$ of damages from her former attorney. Assume further that the fee previously paid to the former attorney equaled $\$ 1,000,000$. In order to exclude the $\$ 300,000$ from gross income under the tax benefit rule, the plaintiff would have to show that $\$ 300,000$ constituted a "recovery" of a portion of the $\$ 1,000,000$ fee originally paid to the attorney for purposes of section 111(a).

If this characterization of the $\$ 300,000$ damages as a recovery of attorney's fee paid were to prevail, the claimant could exclude the damages from gross income under the tax benefit rule. Although the attorney's fee amount was deductible in the year of settlement, the claimant would have received no tax benefit from the deduction because the entire deduction was disallowed in computing her AMT liability. ${ }^{78}$

Therefore, the key question is whether the $\$ 300,000$ of damages is properly characterized as a partial recovery of attorney's fees paid. The damages will be considered a recovery only if there is a sufficient relationship between the damages and the attorney's fees so that "they can be considered as parts of one and the same transaction."

The resolution of this issue may depend on the theory under which the damages were recovered. Recall that, if the claimant proved that the attorney violated his fiduciary duties, the claimant may be awarded (in addition to any actual damages) all or a portion of the fees previously paid to the attorney. The theory underlying this disgorgement of fees is that, by breaching his fiduciary duties, the attorney did not really "earn" the fees. As a result, it appears that any such disgorgement of fees by the attorney back to the claimant should be treated as a refund of excess fees, which would be excludible under the tax benefit rule. Therefore, if the $\$ 300,000$ of damages (or any portion thereof) were received under a disgorgement of fee theory, the $\$ 300,000$ (of such relevant portion) should be excluded from the claimant's gross income.

However, if the claimant is awarded an amount as actual damages

78 See supra Part I (discussing of AMT treatment of attorney fees).

79 Am. Fin. Corp. v. Commissioner, 72 T.C. 506, 510 (1979) (quoting Farr v. Commissioner, 11 T.C. 552, 567 (1948)). 
pursuant to either a fiduciary duty or malpractice claim, the argument that these damages are a recovery for purposes of section 111(a) is much less persuasive. ${ }^{80}$ Unlike in the case of fee disgorgement, there is no direct nexus between the fees paid and the actual damages. In the context of actual damages, the amount of fees paid is irrelevantactual damages can be awarded well in excess of the fees paid; in fact, damages can be awarded even if no fee was charged by the attorney. Simply put, when proving actual damages, the amount of attorney's fees previously paid by the claimant is entirely irrelevant.

On the other hand, the operation of the AMT trap necessarily ties the amount of actual damages to the amount of the attorney's fees paid. Mathematically, actual damages can never exceed the amount of fees paid, and the AMT trap will never occur in cases in which no fee is paid. ${ }^{81}$ Perhaps this nexus might be sufficient to treat an award of actual damages as a partial refund of fees paid. If so, a recovery of actual damages attributable to the AMT trap would be excluded from gross income pursuant to section 111(a).

\section{CONCLUSION}

Recently, the AMT trap has been a pervasive nuisance for tax practitioners and federal judges, and especially for victims with employment discrimination and civil rights claims. In this Essay, I demonstrate that the trap creates very significant ethical, fiduciary duty and malpractice issues for lawyers handling these sorts of claims. A lawyer with knowledge of the AMT trap has an ethical and fiduciary duty to explain the impact of the trap at various critical junctures of the litigation so that the client can make informed decisions. In particular, the AMT trap puts lawyers handling low value/high fee cases in quite an awkward position because of the conflict of interests the trap creates. In addition, trial lawyers without knowledge of the AMT trap may commit malpractice if similarly situated lawyers are aware of the trap. However, the causation requirement of malpractice claims may preclude liability with respect to an unknowing lawyer except in cases in which the AMT trap causes the client's effective tax rate to exceed one hundred percent on her recovery.

${ }^{80}$ The analysis below applies equally to amounts received as actual damages under a fiduciary duty claim.

${ }^{81}$ See Polsky, supra note 3, at 68 (noting that the AMT trap effectively taxes the plaintiff on a portion of the fees which are paid to the attorney); Wood, supra note 7, at 573 (same). 
As commentators have discussed, the optimal solution is to amend the Code to fix the statutory flaw giving rise to the AMT trap. Despite pleas to fix the Code from tax practitioners and academics, Congress has not yet acted. Perhaps if the trial lawyers began to appreciate their duties to advise their clients fully of the trap, as well as their potential exposure to liability, these lawyers might be motivated to use their political clout to encourage Congress to fix the AMT trap. 